\title{
EFFECTS OF 2-HYDROXYBENZOIC ACID ON THE EFFICIENCY OF THE PHOTOSYNTHETIC APPARATUS OF BASKET WILLOW (Salix viminalis L.) PLANT GROWING UNDER CONDITIONS OF SALT STRESS
}

\section{WPŁYW KWASU 2-HYDROKSYBENZOESOWEGO NA WYDAJNOŚĆ APARATU FOTOSYNTETYCZNEGO WIERZBY WICIOWEJ (Salix viminalis L.) ROSNĄCEJ W WARUNKACH STRESU SOLNEGO}

\section{Department of Plant Physiology and Biochemistry, West Pomeranian University}

of Technology, Szczecin, Poland

\begin{abstract}
Streszczenie. Celem badań, przeprowadzonych w 2016 r. w Katedrze Fizjologii Roślin i Biochemii Zachodniopomorskiego Uniwersytetu Technologicznego w Szczecinie, była ocena wpływu egzogennej aplikacji kwasu 2-hydroksybenzoesowego (kwasu salicylowego) na wydajność aparatu fotosyntetycznego wierzby wiciowej rosnącej w warunkach podwyższonego stężenia soli. Pierwszym czynnikiem doświadczalnym było stężenie chlorku sodu (kontrola - pożywka pełna Hoaglanda, 3,0 g NaC I $\cdot \mathrm{dm}^{-3}$ ) drugim czynnikiem - stężenie kwasu 3-hydroksybenzoesowego (kontrola - pożywka pełna, $138 \mathrm{mg} \cdot \mathrm{dm}^{-3}$ ). Klon Tora dobrze tolerował krótki okres ekspozycji na zastosowane stężenie $\mathrm{NaCl}$, o czym świadczą duże wartości takich wskaźników, jak wskaźnik witalności PSII (PI), wskaźnik Area oraz maksymalna potencjalna efektywność reakcji fotochemicznej w PSII, wyznaczona po adaptacji ciemniowej $\left(F_{\mathrm{v}} / F_{\mathrm{M}}\right)$. Dłuższy okres ekspozycji roślin na zasolenie spowodował zmniejszenie u klonu Tora wartości parametru $T_{\mathrm{FM}}$ (czasu wzrostu fluorescencji chlorofilu od początku pomiaru do osiągnięcia maksimum), u klonu 'Bjor' natomiast - PI oraz $F_{\mathrm{V}} / F_{\mathrm{M}}$. Aplikacja kwasu 2-hydroksybenzoesowego wywarła zróżnicowany wpływ na parametry indukcji fluorescencji chlorofilu „a” wierzby wiciowej rosnącej w warunkach stresu solnego. Zastosowanie kwasu 2-hydroksybenzoesowego, przy dłuższej ekspozycji roślin na podwyższone stężenie $\mathrm{NaCl}$, zwiększyło wartości takich parametrów, jak $T_{\mathrm{FM}}$ oraz $F_{\mathrm{V}} / F_{\mathrm{M}}$ u klonu Bjor wierzby wiciowej; w przypadku klonu Tora zmniejszyło wartość wskaźnika PI.
\end{abstract}

Key words: basket willow, fluorescence of chlorophyll a, salt stress.

Słowa kluczowe: wierzba wiciowa, fluorescencja chlorofilu a, stres solny.

\section{INTRODUCTION}

Salix viminalis L. crop has become popular not only for its value as a energy crop, but also for its usefulness in the reclamation of industrial devastated areas (Stolarski 2004). Despite its rapid growth and easy cultivation in nutrient-poor substrate, the use of this plant may be difficult, because of the detrimental effects of salts of various elements, often found in degraded

Corresponding author - Adres do korespondencji: Małgorzata Mikiciuk, Department of Plant Physiology and Biochemistry, West Pomeranian University of Technology, Szczecin, Juliusza Słowackiego 17, 71-434 Szczecin, Poland, e-mail: malgorzata.mikiciuk@zut.edu.pl 
soils in toxic amounts. It is worth noting that amount of sodium chloride, a salt commonly found in mining areas, is rising in the soil globally due to the occurrence of the phenomenon of global warming (Jakubiak and Śliwka 2008). Toxic impact of $\mathrm{NaCl}$ give damage to cell structures, leading to impairment of metabolic pathways and physiological processes of plants. According to many authors, excessive salinity is a limiting factor for photosynthesis. It may damage the PSIl pigments system (Stępień and Kłobus 2006; Wrochna et al. 2007) and may cause disturbances in the transport of electrons. However, there are also reports of high activity of this photosystem under conditions of salt stress, which may be associated with the latest reports on the lack of interaction of reactive oxygen species produced in the plant under the influence of adverse environmental factors on PSII (Photosystem II) light-damaging (Lu et al. 2002; Nishiyama and Murata 2014). Studies on the potential for salt stress reduction show beneficial effects on plants of certain elements such as potassium, silicon and selenium or organic compounds, including 2-hydroxybenzoic acid (salicylic acid). It is a compound belonging to growth regulators group, phenol derivatives, which in conditions of biotic and abiotic stress, is in charge of synthesis induction and accumulation of immune proteins in plant (Ogórek et al. 2011). Studies show that there are beneficial effects of external application of salicylic acid on plants, manifested in the reduction of stress, in many species growing under conditions of elevated salt concentration in soil (Shakirova et al. 2003; Hussein et al. 2007; Faried et al. 2017).

One of the non-invasive methods to determine the efficiency of a photodynamic apparatus and to evaluate the physiological state of a plant is based on the measurement of fluorescence capacity of chlorophyll a. It uses the natural luminescence capacity of assimilation pigments to evaluate the functioning of the PSII (Murchie and Lawson 2013). Fluorimetric methods allow rapid and highly sensitive assessment of both plant responses to stressors as well as the effectiveness of repair mechanisms and the ability of plants to maintain homeostasis under stressful conditions (Murkowski 2002; Skórska 2002).

The purpose of the study was:

- evaluation of the effect of exogenous application of 2-hydroxybenzoic acid on the state of the photosynthetic apparatus of willow growing in elevated salt concentrations

- evaluation of usefulness of the fluorescent method for characterization the physiological state of the different willow genotype under stressed salt conditions

\section{MATERIAL AND METHODS}

The research include two clones of the basket willow (Salix viminalis L.) - Tora and Bjor, whose seedlings (20 centimeters sections of annual shoots) came from the plantation of the Department of Plant Physiology and Biochemistry of the West Pomeranian University of Technology in Szczecin.

With each willow clone selected for testing, in 2016, a two-factor hydroponic experience was performed in the laboratory of the Department of Plant Physiology and Biochemistry in a complete randomized triplication. The first experimental factor was the concentration of sodium chloride (control - complete Hoagland medium, $3.0 \mathrm{~g} \mathrm{NaCl} \cdot \mathrm{dm}^{-3}$ ) and second was the concentration of 3-hydroxybenzoic acid (control - complete Hoagland medium, 
$138 \mathrm{mg} \cdot \mathrm{dm}^{-3}$ ). A single repetition was 5 pieces of plants placed in one container - in one experiment there were 24 conatainers. Glass containers of $1 \mathrm{dm}^{3}$ were used for the experiment. By the time the willow seedlings were rooted and about five centimeters of shoots were formed, they were filled with full medium. After approximately 14 days from the time of placing the plants in the hydroponies, the composition of the media was varied according to the accepted system of experiment.

Chlorophyll fluorescence parameters were recorded using a Handy PEA spectrofluorometer (Hansatech) based on the standard camera procedure. Measurements were made twice during the course of the experiment, after 5 (I term) and 10 days (II term) from the beginning of the experimental exposure period, each in 15 leaves (selected one representative leaf from the plant) from each experimental combination, in the same position on the plant, which was shaded 20 minutes before the measurement with factory clips. By the spectrofluorometer was measured and calculated the following chlorophyll fluorescence induction parameters:

$F_{0}$ - initial fluorescence (zero), excitation energy loss indicator in energy antennas;

$F_{\mathrm{M}}$ - maximum fluorescence, after reduction of acceptors in PS II and after darkening adaptation;

$F_{V}=F_{\mathrm{M}}-F_{0}-$ variable fluorescence, determined after darkening adaptation, parameter dependent on maximum PSII quantum yield;

$F_{\mathrm{V}} / F_{\mathrm{M}}$ - maximum, potential efficiency of photochemical reaction in PS II determined after darkening adaptation, after reduction of acceptors in PS II (Bolhár - Nordenkampf and Öquist 1993);

$T_{\mathrm{FM}}$ - chlorophyll fluorescence growth time from the beginning of the measurement to the maximum $\left(F_{\mathrm{M}}\right)$;

PI (Performance Index) - PS II vitality indicator, which relates to the overall vitality of this system;

$A_{\mathrm{M}}($ Area $)$ - surface above the chlorophyll fluorescence induction curve between the $F_{0}$ and $F_{\mathrm{M}}$ points proportional to the pool size of the reduced plastochinon electron acceptors in PS II. Expressed in units bms (bitomilisecond).

Results of the study were statistically analyzed using a two-way analysis of variation in complete randomization. The significance of differences between means was determined using Duncan's test, with significance level $\alpha=0.05$.

\section{RESULTS AND DISCUSSION}

The metabolic process that regulates the accumulation of biomass by plants, which is particularly sensitive to stress factors, is photosynthesis. An effective method to assess changes in the activity of their photosynthetic apparatus is to analyze the fluorescence signal of the chlorophyll "a". Under natural conditions, the photodynamic apparatus loses from 0.5 to $5 \%$ of the previously absorbed energy in the form of chlorophyll fluorescence. The effective course of the reaction of energetic changes in chloroplasts is characterized by low level of chlorophyll steady fluorescence and the characteristic course of its induction. The impact of stress factors causes both the intensity change and the nature of chlorophyll fluorescence induction (Kalaji and Łoboda 2007; Kuckenberg et al. 2009; Murkowski and Mila 2010). 
In the case of the Tor clone, the influence of experimental factors on the value of $T_{F M}$ parameter, ie the time of chlorophyll fluorescence growth from the beginning of the measurement to the maximum was not showed. Longer plant exposure times for applied $\mathrm{NaCl}$ (measured at II term) resulted in a decrease in $\mathrm{T}_{\mathrm{FM}}$ values compared to control plants. At the same time of measurement, the significance of interaction was also determined. The highest values of $\mathrm{T}_{\mathrm{FM}}$ were found in plants grown in complete medium without the addition of 2-hydroxybenzoic acid (Table 1).

Table 1. Chlorophyll fluorescence growth time from the beginning of the measurement to the maximum $T_{F M}$ in the Tora willow clone

Tabela 1. Czas wzrostu fluorescencji chlorofilu od początku pomiaru do osiągnięcia maksimum $T_{\mathrm{FM}}$ u klonu Tora wierzby wiciowej

\begin{tabular}{lccc}
\hline & $\begin{array}{c}\text { 2-hydroxybenzoic acid } \\
\text { Kwas 2-hydroksybenzoesowy } \\
138 \mathrm{mg} \cdot \mathrm{dm}^{-3}\end{array}$ & $\begin{array}{c}\text { Control Hoagland medium } \\
\text { Kontrola - pożywka pełna } \\
\text { Hoaglanda }\end{array}$ & $\begin{array}{c}\text { Average } \\
\text { Srednia }\end{array}$ \\
\cline { 2 - 4 } & $307.00^{\mathrm{a}}$ & I term - I termin & $288.50^{\mathrm{a}}$ \\
\hline $\begin{array}{l}\mathrm{NaCl} 3.0 \mathrm{~g} \cdot \mathrm{dm}^{-3} \\
\text { Control Hoagland }\end{array}$ & $356.00^{\mathrm{a}}$ & $270.00^{\mathrm{a}}$ & $326.00^{\mathrm{a}}$ \\
$\begin{array}{l}\text { medium } \\
\text { Kontrola - pożywka } \\
\text { pełna Hoaglanda } \\
\text { Average - Średnia }\end{array}$ & $363.00^{\mathrm{a}}$ & $296.00^{\mathrm{a}}$ & \\
\cline { 2 - 4 } & & $283.00^{\mathrm{a}}$ & $272.50^{\mathrm{a}}$ \\
\hline $\begin{array}{l}\text { NaCl } \\
\text { Control - Kontrola }\end{array}$ & $288.00^{\mathrm{a}}$ & II term - II termin & $350.50^{\mathrm{b}}$ \\
Average - Średnia & $294.00^{\mathrm{a}}$ & $257.00^{\mathrm{a}}$ & \\
\hline
\end{tabular}

Averages marked with the same letters do not differ significantly with significance level $\alpha=0.05-$ Średnie oznaczone tymi samymi literami nie różnią się istotnie przy poziomie istotności $\alpha=0,05$.

Addition of this compound to the high salt concentration medium did not affect the value of the $T_{\mathrm{FM}}$ parameter. For the Bjor clone at the first date of measurement, no significant main effects of the experience were found but the significance of the interaction of factors was shown. The smallest $T_{\mathrm{FM}}$ value, significantly different from that found in plants grown under elevated salinity and the interaction of 2-hydroxybenzoic acid, has been demonstrated for plants grown in control medium supplemented with 2-hydroxybenzoic acid. At the second date of measurement in Bjor clone a higher $T_{\mathrm{FM}}$ value was found for plants growing at elevated $\mathrm{NaCl}$ levels and in salicylic acid medium. It was also found that addition of this compound to media with $\mathrm{NaCl}$ and control media increased the $T_{\mathrm{FM}}$ value (Table 2).

The pool of reduced plastochinone electron acceptors in PSII (Area) are one of the best indicators of plant assimilation efficiency measured by detection and analysis of chlorophyll „a” fluorescence signal. In the case of blocking electron transport from reaction centers to plastochinones, which may occur eg. in stress conditions, the value of the $A_{\mathrm{M}}$ parameter decreases (Augustynowicz et al. 2010). In the Tora and Bjor clones, no significant influence of the major experience factors on the value of the $A_{M}$ parameter was found in both measurement dates. The significance of their interaction was shown. In the first measurement, in the case of the Tora clone, the highest value of the $A_{M}$ parameter was found in plants grown in the medium without addition of $\mathrm{NaCl}$, enriched with salicylic acid. In the Bjor clone, on the second measurement date, after prolonged exposure, showed that the addition of salicylic acid to the medium containing $\mathrm{NaCl}$ reduced the value of the $A_{M}$ parameter (Table 3,4$)$. 
Table 2. Chlorophyll fluorescence growth time from the beginning of the measurement to the maximum $T_{\mathrm{FM}}$ in the Bjor willow clone

Tabela 2. Czas wzrostu fluorescencji chlorofilu od początku pomiaru do osiągnięcia maksimum $T_{\mathrm{FM}}$ u klonu Bjor wierzby wiciowej

\begin{tabular}{lccc}
\hline & $\begin{array}{c}\text { 2-hydroxybenzoic acid } \\
\text { Kwas 2-hydroksybenzoesowy }\end{array}$ & $\begin{array}{c}\text { Control } \\
\text { Kontrola }\end{array}$ & $\begin{array}{c}\text { Average } \\
\text { Średnia }\end{array}$ \\
\cline { 2 - 4 } & & I term - I termin & $394.50^{\mathrm{a}}$ \\
\hline $\mathrm{NaCl}^{* *}$ & $446.00^{\mathrm{b}}$ & $343.00^{\mathrm{ab}}$ & $325.50^{\mathrm{a}}$ \\
Control - Kontrola & $304.00^{\mathrm{a}}$ & $347.00^{\mathrm{ab}}$ & $347.00^{\mathrm{b}}$ \\
Average - Średnia & $375.00^{\mathrm{a}}$ & $345.00^{\mathrm{a}}$ & $267.50^{\mathrm{a}}$ \\
\cline { 2 - 4 } & & II term - II termin & \\
\hline $\mathrm{NaCl}$ & $394.00^{\mathrm{a}}$ & $300.00^{\mathrm{b}}$ & $243.00^{\mathrm{a}}$ \\
Control - Kontrola & $292.00^{\mathrm{b}}$ & $271.50^{\mathrm{a}}$ & \\
\hline
\end{tabular}

Explanation see Table 1 - Objaśnienia jak w tab. 1.

Table 3. Surface above the chlorophyll „a" fluorescence induction curve proportional to the pool size of the reduced plastochinon electron acceptors in PSII - $A_{M}$ (Area) [bms], in the Tora willow clone Tabela 3. Powierzchnia nad krzywą indukcji fluorescencji chlorofilu „a”, proporcjonalna do wielkości puli zredukowanych plastochinonowych akceptorów elektronów w PSII - $A_{M}$ (Area) [bms] u klonu Tora wierzby wiciowej

\begin{tabular}{lccc}
\hline & $\begin{array}{c}\text { 2-hydroxybenzoic acid } \\
\text { Kwas 2-hydroksybenzoesowy }\end{array}$ & $\begin{array}{c}\text { Control } \\
\text { Kontrola }\end{array}$ & $\begin{array}{c}\text { Average } \\
\text { Średnia }\end{array}$ \\
\cline { 2 - 4 } & & I term - I termin \\
\hline $\mathrm{NaCl}$ & $50471.50^{\mathrm{a}}$ & $53017.80^{\mathrm{a}}$ & $51744.65^{\mathrm{a}}$ \\
Control - Kontrola & $63081.90^{\mathrm{b}}$ & $47215.80^{\mathrm{a}}$ & $55148.85^{\mathrm{a}}$ \\
Average - Średnia & $56776.70^{\mathrm{a}}$ & $50116.80^{\mathrm{a}}$ & \\
\cline { 2 - 4 } & & II term - II termin \\
\hline $\mathrm{NaCl}$ & $47913.80^{\mathrm{a}}$ & $42627.60^{\mathrm{a}}$ & $45270.70^{\mathrm{a}}$ \\
Control - Kontrola & $48015.50^{\mathrm{a}}$ & $43469.70^{\mathrm{a}}$ & $45742.60^{\mathrm{a}}$ \\
Average - Średnia & $47964.65^{\mathrm{a}}$ & $43048.65^{\mathrm{a}}$ & \\
\hline
\end{tabular}

Explanation see Table 1 - Objaśnienia jak w tab. 1.

Table 4. Surface above the chlorophyll „a” fluorescence induction curve proportional to the pool size of the reduced plastochinon electron acceptors in PSII - $A_{M}$ (Area) [bms], in the Bjor willow clone

Tabela 4. Powierzchnia nad krzywą indukcji fluorescencji chlorofilu „a”, proporcjonalna do wielkości puli zredukowanych plastochinonowych akceptorów elektronów w PSII - Area [bms], u klonu Bjor wierzby wiciowej

\begin{tabular}{|c|c|c|c|}
\hline & $\begin{array}{c}\text { 2-hydroxybenzoic acid } \\
\text { Kwas 2-hydroksybenzoesowy }\end{array}$ & $\begin{array}{c}\text { Control } \\
\text { Kontrola } \\
\end{array}$ & $\begin{array}{l}\text { Average } \\
\text { Średnia }\end{array}$ \\
\hline & \multicolumn{3}{|c|}{ I term - I termin } \\
\hline $\mathrm{NaCl}$ & $46106.70^{a}$ & $53238.00^{a}$ & $49672.35^{a}$ \\
\hline Control - Kontrola & $55948.50^{a}$ & $52886.50^{a}$ & $54417.50^{a}$ \\
\hline \multirow[t]{2}{*}{ Average - Średnia } & $51027.60^{a}$ & $53062.25^{a}$ & \\
\hline & \multicolumn{3}{|c|}{ II term - II termin } \\
\hline $\mathrm{NaCl}$ & $34266.70^{a}$ & $46023.30^{c}$ & $40145.00^{a}$ \\
\hline Control - Kontrola & $45256.20^{\mathrm{bc}}$ & $38681.60^{\mathrm{ab}}$ & $41968.90^{a}$ \\
\hline Average - Średnia & $39761.45^{a}$ & $42352.45^{\mathrm{a}}$ & \\
\hline
\end{tabular}

Explanation see Table 1 - Objaśnienia jak w tab. 1.

In the Tora clone, in both measurement periods the higher PI value was found in plants grown in elevated salinity and in willow grown in salicylic acid-free medium. The addition of this compound to the $\mathrm{NaCl}$-containing medium reduced the value of the $\mathrm{PI}$ index, as determined on the two measurement dates. At the first term, the same dependency was also noted for plants growing in the control medium. In the Bjor clone, after a longer exposure to experimental agents, a higher $\mathrm{PI}$ value showed plants grown in $\mathrm{NaCl}$-free medium. The supply of salicylic acid to plants did not affect this feature in both control growing and high salt concentrations (Table 5, 6). 
Table 5. PS II vitality indicator - PI (Performance Index) in the Tora willow clone Tabela 5. Wskaźnik witalności systemu PS II - PI u klonu Tora wierzby wiciowej

\begin{tabular}{lccc}
\hline & $\begin{array}{c}\text { 2-hydroxybenzoic acid } \\
\text { Kwas 2-hydroksybenzoesowy }\end{array}$ & $\begin{array}{c}\text { Control } \\
\text { Kontrola }\end{array}$ & $\begin{array}{c}\text { Average } \\
\text { Srednia }\end{array}$ \\
\cline { 2 - 4 } & & I term - I termin & $1.640^{\mathrm{b}}$ \\
$\mathrm{nyCl}$ & $1.505^{\mathrm{b}}$ & $1.776^{\mathrm{c}}$ & $1.346^{\mathrm{a}}$ \\
Control - Kontrola & $1.224^{\mathrm{a}}$ & $1.468^{\mathrm{b}}$ & \\
\cline { 2 - 4 } & $1.346^{\mathrm{a}}$ & $1.622^{\mathrm{b}}$ & $1.504^{\mathrm{b}}$ \\
$\mathrm{nyaCl}$ & & $\mathrm{II}$ term - II termin & $1.121^{\mathrm{a}}$ \\
Control - Kontrola & $1.231^{\mathrm{a}}$ & $1.777^{\mathrm{b}}$ & \\
Average - Średnia & $1.074^{\mathrm{a}}$ & $1.169^{\mathrm{a}}$ & $1.473^{\mathrm{b}}$ \\
\hline
\end{tabular}

Explanation see Table 1 - Objaśnienia jak w tab. 1.

Table 6. PS II vitality indicator - PI (Performance Index) in the Bjor willow clone Tabela 6. Wskaźnik witalności systemu PS II - PI u klonu wierzby wiciowej Bjor

\begin{tabular}{|c|c|c|c|}
\hline & $\begin{array}{c}\text { 2-hydroxybenzoic acid } \\
\text { Kwas 2-hydroksybenzoesowy }\end{array}$ & $\begin{array}{l}\text { Control } \\
\text { Kontrola } \\
\end{array}$ & $\begin{array}{l}\text { Average } \\
\text { Średnia }\end{array}$ \\
\hline & \multicolumn{3}{|c|}{ I term - I termin } \\
\hline $\mathrm{NaCl}$ & $1.119^{a}$ & $1.376^{\mathrm{ab}}$ & $1.247^{a}$ \\
\hline Control - Kontrola & $1.459^{b}$ & $1.440^{\mathrm{b}}$ & $1.450^{\mathrm{a}}$ \\
\hline \multirow{2}{*}{ Average - Średnia } & $1.289^{a}$ & $1.408^{a}$ & \\
\hline & \multicolumn{3}{|c|}{ II term - II termin } \\
\hline $\mathrm{NaCl}$ & $0.827^{a}$ & $0.890^{a}$ & $0.858^{a}$ \\
\hline Control - Kontrola & $1.277^{\mathrm{b}}$ & $1.221^{\mathrm{b}}$ & $1.249^{b}$ \\
\hline Average - Średnia & $1.052^{\mathrm{a}}$ & $1.055^{\mathrm{a}}$ & \\
\hline
\end{tabular}

Explanation see Table 1 - Objaśnienia jak w tab. 1.

Table 7. Maximum, potential efficiency of photochemical reaction in PS II determined after darkening adaptation $F_{\mathrm{v}} / F_{\mathrm{M}}$ in the Tora willow clone

Tabela 7. Maksymalna potencjalna efektywność reakcji fotochemicznej w PS II wyznaczona po adaptacji ciemniowej $F_{\mathrm{v}} / F_{\mathrm{M}}$ u klonu Tora wierzby wiciowej

\begin{tabular}{lccc}
\hline & $\begin{array}{c}\text { 2-hydroxybenzoic acid } \\
\text { Kwas 2-hydroksybenzoesowy }\end{array}$ & $\begin{array}{c}\text { Control } \\
\text { Kontrola }\end{array}$ & $\begin{array}{c}\text { Average } \\
\text { Średnia }\end{array}$ \\
\cline { 2 - 4 } & & I term - I termin & \\
\hline $\mathrm{NaCl}$ & $0.819^{\mathrm{b}}$ & $0.829^{\mathrm{b}}$ & $0.824^{\mathrm{b}}$ \\
Control - Kontrola & $0.797^{\mathrm{a}}$ & $0.823^{\mathrm{b}}$ & $0.810^{\mathrm{a}}$ \\
Average - Średnia & $0.808^{\mathrm{a}}$ & $0.826^{\mathrm{b}}$ & \\
\cline { 2 - 4 } & & $\mathrm{II}$ term - II termin & $0.806^{\mathrm{a}}$ \\
$\mathrm{naCl}$ & $0.831^{\mathrm{a}}$ & $0.830^{\mathrm{a}}$ & $0.831^{\mathrm{a}}$ \\
Control - Kontrola & $0.804^{\mathrm{a}}$ & $0.808^{\mathrm{a}}$ & \\
\hline
\end{tabular}

Explanation see Table 1 - Objaśnienia jak $w$ tab. 1.

Table 8. Maximum, potential efficiency of photochemical reaction in PS II determined after darkening adaptation $F \mathrm{v} / F_{\mathrm{M}}$ in the Bjor willow clone

Table 8. Maksymalna potencjalna efektywność reakcji fotochemicznej w PS II wyznaczona po adaptacji ciemniowej $F_{\mathrm{v}} / F_{\mathrm{M}} \mathrm{u}$ klonu wierzby wiciowej Bjor

\begin{tabular}{|c|c|c|c|}
\hline & $\begin{array}{c}\text { 2-hydroxybenzoic acid } \\
\text { Kwas 2-hydroksybenzoesowy }\end{array}$ & $\begin{array}{l}\text { Control } \\
\text { Kontrola }\end{array}$ & $\begin{array}{l}\text { Average } \\
\text { Średnia }\end{array}$ \\
\hline & \multicolumn{3}{|c|}{ I term - I termin } \\
\hline $\mathrm{NaCl}$ & $0.740^{\mathrm{a}}$ & $0.808^{b}$ & $0.774^{a}$ \\
\hline Control - Kontrola & $0.809^{b}$ & $0.815^{b}$ & $0.812^{\mathrm{a}}$ \\
\hline \multirow{2}{*}{ Average - Średnia } & $0.774^{\mathrm{a}}$ & $0.811^{a}$ & \\
\hline & \multicolumn{3}{|c|}{ II term - II termin } \\
\hline $\mathrm{NaCl}$ & $0.699^{b}$ & $0.592^{a}$ & $0.645^{\mathrm{a}}$ \\
\hline Control - Kontrola & $0.814^{\mathrm{c}}$ & $0.791^{c}$ & $0.802^{b}$ \\
\hline Average - Średnia & $0.756^{a}$ & $0.691^{a}$ & \\
\hline
\end{tabular}

Explanation see Table 1 - Objaśnienia jak w tab. 1. 
The $F_{\mathrm{V}} / F_{\mathrm{M}}$ parameter is considered to be a measure of the photochemical activity of a plant photosynthetic apparatus. Under optimal growth conditions according to Angelini et al. (2001) its value should be about 0.85 relative units. The reduction in this parameter is a symptom of the stress of photoinhibition. The effect of elevated salt concentrations on the photochemical activity of the plant's photosynthetic apparatus depends on the salinity, the exposure time to this stressor, and the plant species. Jimenez et al. (1997) in rose, Stępien and Kołbus (2006) in cucumber and Wrochna et al. (2007) in Amaranthus paniculatus found that $F_{\mathrm{V}} / F_{\mathrm{M}}$ parameter was increased after a short time after treatment plant with $\mathrm{NaCl}$ and was decreased when the exposure time to salinity was increased. In the case of rose and cucumber, higher decreases of $F_{\mathrm{V}} / F_{\mathrm{M}}$ parameter were observed after treatment of the plants with higher doses of salt. In Lu et al. (2002) research, there was no negative effect of salinity on Suaeda salsa photosynthetic apparatus. In this study, in the Tora clone, after 5 days of exposure to experimental factors, a higher $F_{\mathrm{V}} / F_{\mathrm{M}}$ value was found in plants grown in elevated salinity and in plants from medium with salicylic acid. The addition of this compound to the medium containing $\mathrm{NaCl}$ did not affect the $F_{\mathrm{v}} / F_{\mathrm{M}}$ value. For the Bjor clone, in the second term of the study a higher $F_{\mathrm{v}} / F_{\mathrm{M}}$ value was found in plants grown in medium without $\mathrm{NaCl}$. At the same time, in the case of plants growing in elevated salts, $F_{\mathrm{V}} / F_{\mathrm{M}}$ was also increased due to salicylic acid action. The inverse relationship was noted - the enrichment of $\mathrm{NaCl}$ medium and salicylic acid resulted in a decrease in $F_{\mathrm{V}} / F_{\mathrm{M}}$ in the first term of the study.

\section{CONCLUSIONS}

1. The Tora, the clone of basket willow, well tolerated a short exposure period for the $\mathrm{NaCl}$ concentration, as indicated by high values of $\mathrm{PI}, A_{\mathrm{M}}$, and $F_{\mathrm{V}} / F_{\mathrm{M}}$.

2. Longer plant exposure to salinity resulted in a decrease $T_{F M}$ parameters in Tora clone, and $\mathrm{PI}$ and $F_{\mathrm{V}} / F_{\mathrm{M}}$ in Bjor clone.

3. The application of 2-hydroxybenzoic acid had a different effect on chlorophyll "a" fluorescence induction parameters of basket willow growing under stressed salt conditions.

4. The use of 2-hydroxybenzoic acid in prolonged exposure of plants to elevated $\mathrm{NaCl}$ increased parameters such as $T_{\mathrm{FM}}$ and $F_{\mathrm{V}} / F_{\mathrm{M}}$ in the Bjor clone.

5. The use of 2-hydroxybenzoic acid under saline stress conditions reduced the value of the $\mathrm{PI}$ index in the basket willow.

\section{REFERENCES}

Angelini G., Ragni P., Esposito D., Giardi P., Pompili M.L., Moscardelli R., Giardi M.T. 2001. A device to study the effect of space radiation on photosynthetic organisms. Phys. Med. 17 (Suppl. 1), 267-268.

Augustynowicz J., Pietkiewicz S., Kalaji M.H., Russel S. 2010. Wpływ nawożenia osadem ściekowym na wybrane parametry biologii gleby oraz wydajności aparatu fotosyntetycznego ślazowca pensylwańskiego (Sida hermaphrodita (L.) Rusby) [Microbiological state of soil and efficiency of photosynthetic apparatus of Virginia mallow (Sida hermaphrodita (L.) Rusby) fertilized with sludge obtained from wastewater treatment stations]. Nauka Przyr. Technol. 4(6), 1-11. [in Polish]

Bolhár-Nordenkampf H.R., Öquist G. 1993. Chlorophyll fluorescencje as a total in photosynthesis research. in: Photosynthesis and production $\mathrm{n}$ a changing environment. Eds. D.O. Hall et al. London, Chapman and Hall, 193-206. 
Faried H.N., Ayyub C.M., Amjad M., Ahmed R., Wattoo F.M., Butt M., Bashir M., Shaheen M.R., Waqas M.A. 2017.Salicylic acid confers salt tolerance in potato plants by improving water relations, gaseous exchange, antioxidant activities and osmoregulation. J. Sci. Food Agric. 97, 1868-1875.

Hussein M.M., Balbaa L.K., Gaballah M.S. 2007. Salicylic acid and salinity effects of growth of maize plants. Res. J. Agric. Biol. Sci. 3(4), 321-328.

Jimenez M.S., Gonzales-Rodrigues A.M., Morales D., Cid M.C., Socarro A.R., Caballero M. 1997. Evaluation of chlorophyll fluorescence as a total for salt stress detection in roses. Photosynthetica 33, 291-301.

Jakubiak M., Śliwka M. 2008. Zagospodarowanie i rekultywacja terenów o podwyższonym zasoleniu, zdegradowanych w wyniku działalności górniczej [Management and reclamation of lands with raised soil salinity degraded by activity of mining industry]. Gosp. Sur. Min. 24(3),3. [in Polish]

Kalaji M.H., Łoboda T. 2007. Photosystem II of barley seedlings under cadmium and lead stress. Plant Soil. Environ. 53, 511-516.

Kuckenberg J., Tartachnyk I., Noga G. 2009. Temporal and spatial changes of chlorophyll fluorescence as a basis for early and precise detection of leaf rust and powdery mildew infections in wheat leaves. Precis. Agric. 10, 34-44.

Lu C., Qiu N., Lu Q., Wang B., Kuang T. 2002. Does salt stress lead to increased susceptibility of photosystem II to photoinhibition and changes in photosynthetic pigments composition in halophyte Suaeda salasa grown outdoor. Plant Sci. 163, 1063-1068.

Marchie E.H., Lawson T. 2013. Chlorophyll fluorescencje analysis: a guide to goud practise and understanding some new application. J. Exp. Bot. 13, 3983-3998

Murkowski A. 2002. Fotoinhibicja i stres oksydacyjny. Oddziaływanie czynników stresowych na luminescencję chlorofilu w aparacie fotosyntetycznym roślin uprawnych. Monografia. Acta Agroph. 61, 108-123. [in Polish]

Murkowski A., Mila A. 2010. Wpływ podwyższonego stężenia $\mathrm{CO}_{2}$ na fluorescencję chlorofilu i fotosyntezę wybranych genotypów rzepaku ozimego [The effect of increased $\mathrm{CO}_{2}$ concentration in atmosphere on chlorophyll fluorescence and photosynthesis of some genotypes of winter oilseed rape]. Rośl. Oleiste - Oilseed Crops 31, 283-292. [in Polish]

Nishiyama Y., Murata N. 2014. Revised scheme for the mechanisms of photoinhibition and its application to enhance the abiotic stress tolerance of the photosynthetic machinery. Appl. Microbiol. Biot. 98, 8777-8796.

Ogórek R., Pusz W., Słubicki W. 2011. Wpływ biostymulatorów Asashi SL, Sunagreen oraz Hergit na wzrost wybranych gatunków grzybów [The effect of biostimulators Asahi SL, Sunagreen and Hergit on the development of some species fungi]. Prog. Plant Protect. 51(2), 672-677. [in Polish]

Shakirova M.F., Sakhabutolinova A.R., Bezrukova R.A., Fatkhutolinova D.R. 2003. Changes in the hormonal status of wheat seedlings induces by salicylic acid and salinity. Plant Sci. 164, 3, 317-322.

Skórska E. 2002. Chlorophyll fluorescence of UV -B irradiated bean leaves subjected to chilling in light. Zesz. Probl. Post. Nauk Rol. 481, 391-394.

Stępień P., Kłobus G. 2006. Water relations and photosynthesis in Cucumis sativus L. leaves under salt stress. Biol. Plant. 50(4), 610-616.

Stolarski M. 2004. Produkcja oraz pozyskiwanie biomasy z wieloletnich upraw roślin energetycznych [Production and harvesting of biomass from perennial energy crops]. Probl. Inż. Rol. 3(45), 47-56. [in Polish]

Wrochna M., Gawrońska H., Borkowska B., Gawroński S. 2007. Wpływ zasolenia na akumulację biomasy i fluorescencję chlorofilu u roślin trzech odmian szarłatu ozdobnego [The effect of salinity on biomass accumulation and chlorophyll fluorescence in plants of three cultivars of ornamental amaranth]. Rocz. AR Pozn. 383, 235-239. [in Polish] 
Abstract. The study conducted in 2016 at the Department of Plant Physiology and Biochemistry at the West Pomeranian University of Technology in Szczecin was to evaluate the effect of exogenous application of 2-hydroxybenzoic acid (salicylic acid) on the efficiency of the photosynthetic apparatus of basket willow growing under conditions of elevated salt concentration. The first experimental factor was the concentration of sodium chloride (control complete Hoagland medium, $3.0 \mathrm{~g} \mathrm{NaCl} \cdot \mathrm{dm}^{-3}$ ) and second was the concentration of 3-hydroxybenzoic acid (control - complete Hoagland medium, $138 \mathrm{mg} \cdot \mathrm{dm}^{-3}$ ). The Tora clone tolerated a short period of exposure to the $\mathrm{NaCl}$ concentration, as evidenced by high values of Performance Index (PI), Area, and maximum, potential efficiency of photochemical reaction in PS II determined after darkening adaptation, after reduction of acceptors in PS II $\left(F_{\mathrm{v}} / F_{\mathrm{M}}\right)$. Longer plant exposure to salinity resulted in a decrease value of $T_{\mathrm{FM}}$ parameter in the Tora clone, and $\mathrm{PI}$ and $F_{\mathrm{v}} / F_{\mathrm{M}}$ in Bjor clone. The application of 2-hydroxybenzoic acid had a varied effect on chlorophyll "a" fluorescence induction parameters of basket willow growing under salt stress conditions. The use of 2-hydroxybenzoic acid increased the parameters such as chlorophyll fluorescence growth time from the beginning of the measurement to the maximum ( $\left.T_{\mathrm{FM}}\right)$ and $F_{\mathrm{V}} / F_{\mathrm{M}}$ in the Bjor clone with prolonged exposure to higher $\mathrm{NaCl}$ concentrations. For the Tora clone, the PI value decreased. 
